Acta vet. scand. $1970,11,571-576$.

From the Department of Medicine I, Royal Veterinary College, Stockholm, Sweden.

\title{
BLOOD SELENIUM IN NATURALLY FED HORSES AND THE EFFECT OF SELENIUM ADMINISTRATION*)
}

By

G. Bergsten, R. Holmbäck and P. Lindberg

Information on selenium content in blood and tissues of some domestic species like sheep, cattle and swine is gradually increasing in the current literature. The data are few with regard to the horse, however. This is somewhat surprising since to our knowledge selenium therapy in horses is often used.

Stowe (1967) published serum selenium levels in horses of varying age groups which were fed natural or experimental rations. He observed a low selenium status in suckling foals, and suggested an absorption inhibiting effect of mare's milk on dietary selenium.

We have determined selenium in whole blood of adult horses which were given natural rations, and in suckling foals. The effect of selenium administration on blood selenium was followed in some experiments.

\section{MATERIAL AND METHODS}

All horses except one used in this study were trotters. Blood samples were collected from 34 mares and 19 suckling foals at 3 farms in the middle part of Sweden and at the Royal Veterinary College, Stockholm. Blood was drawn from the vena jugularis in heparin, milk samples were taken from 8 mares.

Food, hay and oats as major components, was collected at 2 farms and at the medical clinic. Selenium was administered as

*) Supported by grants from Statens Råd för Skogs- och Jordbruksforskning. 
sodium selenite mixed in the food. The preparation used was Tocosel Pharmacia (Sodium selenite, $0.4 \mathrm{mg} / \mathrm{g}$ as $\mathrm{Se}^{4+}$, Tocophenyl acetate $20 \mathrm{mg} / \mathrm{g}$ ). Details are given in Results. The method for selenium determination in blood, milk and food has been described previously (Lindberg 1968).

\section{RESULTS}

Blood selenium values of mares and suckling foals are shown in Table 1.

At Vädersjö the ration consisted of only hay and oats. The average selenium content of the ration was calculated from selenium concentration as determined for each component, and the relative proportions of components, to be at Vädersjö $20.1 \mathrm{ng} / \mathrm{g}$, att Gällringssund $19 \mathrm{ng} / \mathrm{g}$, and at the medical clinic $41.6 \mathrm{ng} / \mathrm{g}$.

T a b l e 1. Whole blood selenium (mean $\pm \mathrm{s} . \mathrm{ng} / \mathrm{ml}$ ) in adult horses and suckling foals.

\begin{tabular}{|c|c|c|}
\hline Farm & Adult horses (no.) & Suckling foals (no.) \\
\hline Stalbo & $26.1 \pm 12.7(10)$ & $34.3 \pm 15.4(9)$ \\
\hline Vädersjö & $25.8 \pm 6.7(10)$ & $28.8 \pm 6.1(5)$ \\
\hline Gällringssund ${ }^{1}$ ) & $\left.22^{2}\right) ; 28 ; 31(3)$ & \\
\hline Medical clinic, $\mathrm{RVC}^{3}$ ) & $45.3 \pm 8.0(6)$ & \\
\hline
\end{tabular}

1) Individual values.

2) A Norwegian fjord horse.

3) Royal Veterinary College.

All mother mares of the 14 suckling foals in Table 1 are included in adult horses. The correlation of blood selenium in mother mares and suckling foals is shown in Fig. 1. This figure also includes values for 5 other mares with foals, 4 from the medical clinic and 1 from Stalbo which had received selenium in the food.

It appears from Fig. 1 that blood selenium of the suckling foal is higher than blood selenium of the corresponding mare at low selenium levels, i.e. $<40 \mathrm{ng}$, (mean difference $6.6 \pm 1.1$ ( $\mathrm{n}=15$ ), $\mathrm{P}<0.001$ ). At high selenium levels the proportion may be reversed, i.e. the mare's blood is higher in selenium than that of the foal (mean difference $13.6(n=9) \pm 6.8)(P<0.1)$ (see further under Discussion). 


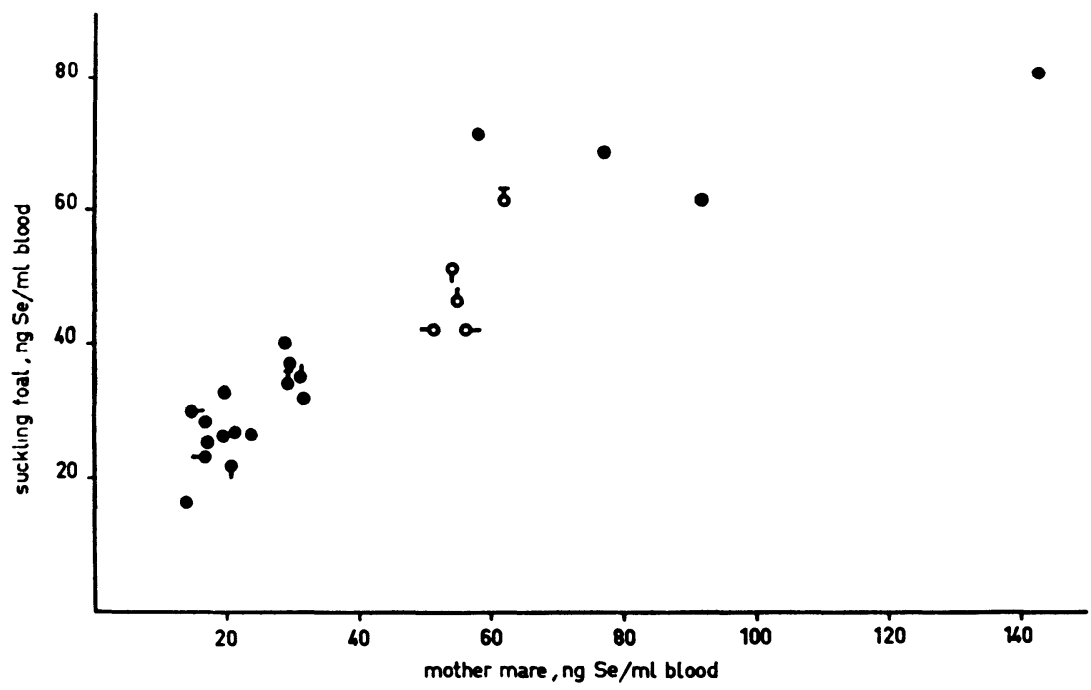

F i g u r e 1. Correlation between blood selenium of 19 mother mares and their suckling foals (partly extracted from Table 1). Five pairs

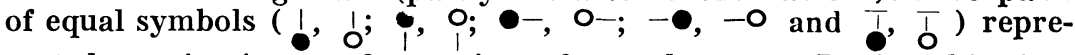
sent determinations at 2 occasions, 2 months apart. During this time the mare was given $6 \mathrm{mg}$ Se once a week. Closed circles present blood values before selenium administration.

$\mathrm{ng} \mathrm{Se} / \mathrm{ml}$ blood
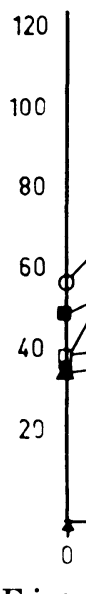

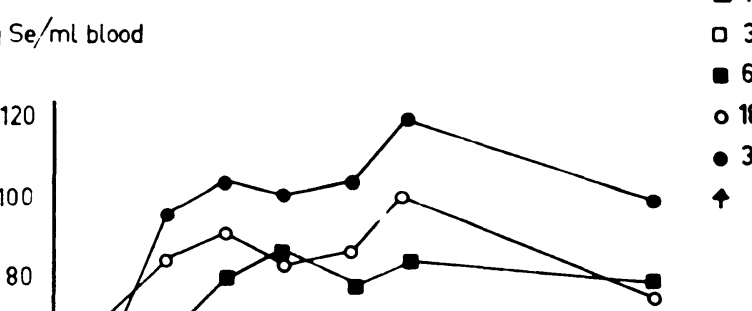

mg Se once a week

$\Delta 1,5 \quad$ "

0 ... . .

- 6 .. .

० 18

30

selenium administration

Fig u r e 2. Blood selenium in horses which were given selenium at intervals (arrows). Blood was drawn at least a week after the last selenium administration except at 2 occasions (3rd and 4th arrows from the left) when blood samples were taken by mistake about $2 \mathrm{hrs}$. after selenium had been given. 
The effect of varying levels of selenium administration on the selenium blood content was studied in 5 horses (Fig. 2).

Blood was drawn at least a week after the last selenium administration except at 2 occasions (3rd and 4th arrows from the left) when blood samples were taken by mistake about 2 hrs. after selenium was given.

T a b l e 2. Blood selenium (ng/ $\mathrm{ml}$ ) of mares and their respective foals (all extracted from Fig. 1), and corresponding mare's milk.

\begin{tabular}{|c|c|c|}
\hline \multicolumn{2}{|c|}{ Mare } & \multirow{2}{*}{$\begin{array}{l}\text { Foal } \\
\text { blood }\end{array}$} \\
\hline blood & milk & \\
\hline 92 & 12 & 61 \\
\hline 77 & 11 & 69 \\
\hline 31 & 3 & 35 \\
\hline 30 & 5 & 34 \\
\hline 21 & 3 & 22 \\
\hline 19 & 6 & 26 \\
\hline 17 & 2 & 23 \\
\hline 15 & 3 & 30 \\
\hline
\end{tabular}

T a b l e 3. Partition of selenium in blood plasma $(\mathrm{ng} / \mathrm{ml})$ and blood corpuscles ( $\mathrm{ng} / \mathrm{g}$ ) in horses. Plasma and corpuscles were separated (heparinized blood) by centrifugation at 2500 r.p.m. for $15 \mathrm{~min}$. The blood corpuscles were not washed.

\begin{tabular}{ccc}
\hline Whole blood & Plasma & Corpuscles \\
\hline 103 & 120 & 100 \\
86 & 94 & 90 \\
89 & 72 & 92 \\
55 & 47 & 77 \\
39 & 35 & 42 \\
56 & 57 & 64 \\
\hline
\end{tabular}

In a number of cases the selenium content of the mare's milk was determined (Table 2). The table shows blood selenium of mares and their respective foals (all extracted from Fig. 1), and corresponding mare's milk.

The partition of selenium between blood plasma and blood corpuscles is shown in Table 3 .

\section{DISCUSSION}

The horses shown in Table 1 had not obtained any extra selenium on top of what their food contained, as far as could be ascertained. As blood selenium varies rather closely with the amount of selenium of the food (Lindberg $\&$ Jacobsson 1970) it is difficult to establish a physiological level, unless cases of manifested selenium deficiency are considered. Swedish forages are on the whole low in selenium (Lindberg 1968). When the blood selenium values of horses at Vädersjö, Gällringssund, and the Medical Clinic are compared with the food selenium, it appears that $\simeq 25 \mathrm{ng} \mathrm{Se} / \mathrm{ml}$ blood corresponds to $\simeq 20 \mathrm{ng} \mathrm{Se} / \mathrm{g}$ food, and $\simeq 45 \mathrm{ng} \mathrm{Se} / \mathrm{ml}$ blood to $\simeq 41 \mathrm{ng} \mathrm{Se} / \mathrm{g}$ food. This indi- 
cates that, within certain limits, the correlation between blood selenium and food selenium is close. Sinilar conclusions seem to be warranted from the relations of blood selenium of mares and foals, and of mares' milk (Table 2).

The horses at Vädersjö, Gällringssund and the Medical Clinic (Table 1) had been fed the same ration for a long time, i. e. several months at least. They had apparently reached a fair steady state with regard to selenium intake, which is reflected in low standard deviations. At Stalbo, however, most horses had arrived to the farm a rather short time before. No determination of selenium was done in the Stalbo food, because it was not considered to be representative for the previous selenium intake of the horses. It is seen that the standard deviations of the Stalbo horses are relatively high.

Stowe (1967) found serum levels of selenium in naturally fed weanlings and adult horses between 104.7 and $162.1 \mathrm{ng} / \mathrm{ml}$ (averages of groups of horses). He did not determine food selenium, but the serum values indicate a significantly higher selenium intake than in the present material. The selenium content of blood plasma and of whole blood is about the same (Table $3)$.

Suckling foals had significantly lower serum selenium than adult horses in Stowe's material. A corresponding relation can be observed in the present material, but only when the blood selenium values are high (Fig. 1), i. e. when the mother mares had been treated with a selenium preparation. This, and also Stowe's data, may be explained so that excess selenium is eliminated mainly via other channels than milk.

The effect on blood Se of various dose levels is shown in Fig. 2. As expected blood levels increase with increased dosage but linearily only between 1.5 and $6 \mathrm{mg}$. The response of $3 \times 6 \mathrm{mg}$ and $5 \times 6 \mathrm{mg}$ dosage is only slightly greater than that of $6 \mathrm{mg}$. This would indicate that the $6 \mathrm{mg}$ amount corresponds fairly to the actual need. A larger part of higher doses is eliminated as an unphysiological excess. It is of interest that the $6 \mathrm{mg}$ dose corresponds to what is conventionally used in Sweden. 


\section{REFERENCES}

Lindberg, P.: Selenium determination in plant and animal material, and in water. Acta vet. scand. 1968. Suppl. 23.

Lindberg, P. \& S. O. Jacobsson: Relationship between selenium content of forage, blood and organs of sheep, and lamb mortality rate. Acta vet. scand. $1970,11,49-58$.

Stowe, $H$. D.: Serum selenium and related parameters of naturally and experimentally fed horses. J. Nutr. 1967, 93, 60-64.

\section{SUMMARY}

Blood Se of adult horses was 26.1, 25.8, and $27.0 \mathrm{ng} / \mathrm{ml}$ (mean values at 3 farms), where the Se of food was about $20 \mathrm{ng} / \mathrm{g}$ dry substance. Experimental adult horses which received about $41 \mathrm{ng} \mathrm{Se} / \mathrm{g}$ food showed $45.3 \mathrm{ng} / \mathrm{ml}$ blood.

At low Se intake suckling foals show higher blood Se than mares, but with high Se intake, the opposite will occur. This is reflected in milk Se, which raises but slowly with rise of mare's blood Se.

Se in blood plasma and in blood corpuscles is on the same level. The effect of various dose levels of Se on blood Se was studied: From 1.5 to $6 \mathrm{mg} \mathrm{Se} /$ week, blood Se rose rather linearily; 18 and $30 \mathrm{mg}$ $\mathrm{Se} /$ week gave but slightly more effect than $6 \mathrm{mg}$.

\section{SAMMANFATTNING}

Selenhalten $i$ blod hos normalt utfodrade hästar och effekten av selenadministration.

Selenhalten i blod hos vuxna hästar var $26.1,25.8$ och $27.0 \mathrm{ng} / \mathrm{ml}$ (medelvärde på 3 stuterier) där fodrets selenhalt var omkring $20 \mathrm{ng} / \mathrm{g}$ torrsubstans. Vuxna försökshästar som erhöll omkring $21 \mathrm{ng} \mathrm{Se} / \mathrm{g}$ foder uppvisade $45.3 \mathrm{ng} / \mathrm{ml}$ blod.

Vid lågt Se-intag visar diande föl högre selenhalt $i$ blodet än stona, men med högt selenintag inträffar det motsatta. Detta återspeglas $i$ mjölkens selenhalt som sakta stiger med stegring i stonas blodselenhalt.

Selenhalten i blodplasma och blodkroppar ligger på samma nivå. Effekten av olika givor Se på blodselenhalten studerades. Vid från 1.5 till $6 \mathrm{mg} \mathrm{Se} /$ vecka steg blodselenhalten ganska lineärt; 18 och 30 $\mathrm{mg} \mathrm{Se} /$ vecka hade endast obetydligt bättre effekt än $6 \mathrm{mg}$. 